Kristijan Juran

\author{
94(497.5Trogir)"1530/1600" \\ Primljeno: 24. 2. 2020. \\ Prihvaćeno: 28. 2. 2020. \\ Izvorni znanstveni rad \\ https://doi.org/10.22586/pp.v39i58.10321
}

\title{
Vratkovići i drugi Morlaci u trogirskome distriktu u 16. stoljeću
}

\begin{abstract}
Recentna je historiografija iznjedrila nekolicinu zapaženih radova o mletačko-osmanskim odnosima na trogirskome pograničju u 16. stoljeću i ulozi koju su u njima imali novodoseljeni osmanski Morlaci. Iako je i ovaj prilog usmjeren k istome cilju, temeljna mu je nakana rasvijetliti još uvijek zamućenu i nedovoljno razrađenu problematiku prisutnosti morlačkih plemena (katuna) u pojedinim selima trogirskoga distrikta u razdoblju od 1530. do 1600. godine. Ovdje se o njima donose nove vijesti, uglavnom iz arhivskih spisa trogirske provenijencije.
\end{abstract}

Ključne riječi: Morlaci, Vratkovići, Popovići, Vasarovići, Trogir, Zagora, 16. stoljeće

\section{Uvod}

Potkraj 15. i u prvim desetljećima 16. stoljeća kontinentalne su dijelove Mletačke Dalmacije, posebice rubna naselja prema ugarsko-hrvatskome (od 1527. habsburškome) i osmanskome teritoriju, zahvatili snažni migracijski procesi koji su rezultirali trajnim iseljenjem starosjeditelja (onih koje nije zadesila sudbina sužnja ili usmrćenika) i doseljenjem Morlaka osmanske provenijencije. U vrtlogu tih promjena našao se, dakako, i trogirski distrikt. Opće povijesne prilike u kojima osmanski Morlaci pristižu na trogirsko područje dobro su pojašnjene u radovima recentnih povjesničara S. Buzov, K. Kužića, C. Luce i D. Caciur, koji su također razradili modalitete te iscrtali dinamiku političko-gospodarskih odnosa između doseljenika s jedne i mletačkih vlasti odnosno trogirske upravne i zemljoposjedničke elite s druge strane tijekom prvih desetljeća njihova suživota. ${ }^{1}$ Ovaj smo prilog sagradili upravo na tim historiografskim temeljima podupirući ih recentnom studijom o doseobi osmanskih Morlaka u sela šibenskoga zaleđa jer se morlačko zaposjedanje rubnih dijelova trogirskoga

Kristijan Juran, Odjel za povijest, Sveučilište u Zadru, Ruđera Boškovića 5, 23000 Zadar, Republika Hrvatska, E-mail adresa: kjuran@unizd.hr

1 Krešimir Kužić, "Prilog biografiji nekih Kačićevih vitezova te podrijetlu stanovništva njihova kraja", Radovi Zavoda za povijesne znanosti HAZU u Zadru 47 (2005): 191-224; Cristian Luca, "The Vlachs/Morlaks in the Hinterlands of Traù (Trogir) and Sebenico (Šibenik), Towns of the Venetian Dalmatia, during the 16th century", u: Miscellanea Historica et Archaeologica in Honorem Professoris Ionel Cândea, ur. Valeriu Sîrbu, Cristian Luca (Braila: Editura Istros a Muzeului Brailei, 2009), 311-322; Snježana Buzov, "Petrova gora, vlaška nahija", Godišnjak Titius: godišnjak za interdisciplinarna istraživanja porječja Krke 4 (2011), br. 4: 313-361; Dana Caciur, "Considerations Regarding the Status of the Morlachs from the Trogir's Hinterland at the Middle of the 16th Century: Being Subjects of the Ottoman Empire and Land Tenants of the Venetian Republic", Res Historica: czasopismo Instytutu Historii UMCS 41 (2016): 95-110. 
distrikta odvijalo u istim okolnostima i na isti način kao i na susjednome šibenskom teritoriju. ${ }^{2}$ Stoga se ne kanimo baviti onim što je već poznato, nego nam je cilj donijeti nove podatke o morlačkome stanovništvu trogirskih sela u 16. stoljeću, uz najnužniju povijesnu kontekstualizaciju.

Područje trogirske i šibenske Zagore, s kojega je stanovništvo povremeno i privremeno iseljavalo tijekom ranijih osmanskih upada, konačno je opustjelo za Mletačko-osmanskoga rata 1499. - 1502. godine. Život se u njemu trajnije obnavlja nakon 1525. godine kada je sporazumom o otvaranju carinske postaje u Šibeniku omogućena nesmetana trgovačka komunikacija između mletačkih i osmanskih podanika. ${ }^{3}$ Upravo toj godini pripadaju najranije vijesti koje govore o dolasku morlačkih stočara s osmanskoga teritorija na ljetne pašnjake uz granicu trogirskoga distrikta. ${ }^{4} \mathrm{U}$ sljedećim su se godinama Morlaci trajno smjestili u nekolicini trogirskih sela, o čemu svjedoče vijesti o deset kršćanskih obitelji u selu Ljubitovici (osmanski porezni popis 1528. - 1530.), ${ }^{5}$ Morlaku Milovcu Vukotiću iz Podboraje (1529. ${ }^{6}$ te Morlacima Popovićima u Zbičju (1530.). ${ }^{7}$ Mlečani su zbog uzurpacije svojih posjeda intervenirali kod osmanskih vlasti, koje su im 1533. godine priznale teritorijalnu ingerenciju nad spornim trogirskim (i šibenskim) selima te naložile Morlacima da ih napuste. Međutim, Morlaci su pronašli drugačije rješenje: sklopili su ugovor o zakupu s vlasnicima zemljišta te su tako legalizirali svoj naseljenički status ostajući i dalje u zaposjednutim selima. ${ }^{8}$ Poznata su dva takva ugovora s početka 1534 . godine, od kojih je jedan sklopljen između trogirske obitelji Cippico i Morlaka naseljenih u njihovu selu Radošiću, dok su u drugome plemenita braća Andreis uredili svoje zemljišnopravne odnose s Morlacima u Zbičju. Starješina morlačke zajednice u Radošiću bio je tada Radoslav Bubetić, a one u Zbičju Juraj Šimunić. ${ }^{9}$ Nakon osmanskih uspjeha u ratu 1537. - 1540. ponovno dolazi do diplomatskih nesuglasja zbog trogirskih (i šibenskih) sela jer se Morlaci nisu pridržavali ugovorenih obveza prema vlasnicima zemljišta. Neriješena jurisdikcijska i zemljišnopravna pitanja, u kontekstu mletačko-osmanskih odnosa

2 Kristijan Juran, “Doseljavanje Morlaka u opustjela sela šibenske Zagore u 16. stoljeću”, Povijesni prilozi 33 (2014), br. 46: 129-160.

3 Juran, "Doseljavanje Morlaka", 133. U sporu oko vlasništva nad dijelom sela Labina, koji se pred trogirskim sudom vodio 1533. i 1534. godine, zapisano je da su osmanski Morlaci došli u trogirska sela dapoi che per interuento del clarissimo misser Piero Zen fo contratata et fata la pace tra la Illustrissima Signoria et Serenissimo Gran Signor odnosno da poi fatta la pace cum li Turchi et dapoi messa la gabella a Sibenico (Hrvatska (dalje: HR) - Državni arhiv u Zadru, Zadar (dalje: DAZD) fond 18 - Općina Trogir (dalje: OT), kut. 6, fasc. 23, fol. 62v-63r. Budući da ćemo se dalje obilato pozivati na arhivski fond Općine Trogir u Državnome arhivu u Zadru, neophodno je na ovome mjestu iznijeti važnu napomenu. Naime, arhivske signature koje u ovome radu rabimo možda neće (sve) odgovarati postojećim signaturama jer je navedeni fond u međuvremenu pretrpio reinventarizaciju.

4 Luca, "The Vlachs/Morlaks", 315.

5 Aleksandar Jakovljević, Neven Isailović, Petrovo polje u vrelima osmanskog razdoblja (1528. - 1604.) (Šibenik: Državni arhiv u Šibeniku; Javna ustanova Nacionalni park Krka, 2019), 451.

6 HR-DAZD-18-OT, kut. 69, fasc. 8, fol. 224r.

7 Kužić, "Prilog biografiji”, 212.

$8 \quad$ Luca, "The Vlachs/Morlaks", 315-316; Juran, "Doseljavanje Morlaka", 134-137.

9 Caciur, "Considerations Regarding the Status of the Morlachs", 100-101. 
na dalmatinskome pograničju, ostala su trajnim obilježjem trogirske povijesti 16 . stoljeća. ${ }^{10}$

Svoju ćemo pozornost dalje usmjeriti konkretnim podacima o rasprostranjenosti pojedinih morlačkih katuna odnosno plemensko-teritorijalnih zajednica na području trogirskoga distrikta u razdoblju od 1530. do 1600. godine. U arhivskim se vrelima toga doba mogu prepoznati tri dominantna katuna: Vratkovići, Popovići i Vasarovići. Vratkoviće i Popoviće poznaje i dosadašnja literatura, koja ih na temelju izvora iz druge polovice 17. stoljeća smješta na prostor od Boraje do Segeta (Vratkovići) odnosno od Labina do Radošića (Popovići). ${ }^{11}$ Takvu topografiju u određenoj mjeri potvrđuju i vrela iz 16. stoljeća.

\section{Vratkovići}

Najbrojnija katunska zajednica u trogirskome distriktu bili su Vratkovići, a primarna im staništa valja tražiti u zapadnoj Hercegovini. ${ }^{12}$ Vijest koju donosi B. Hrabak - da su još 1400. godine zabilježeni u zadarskome zaleđu - smatramo nepouzdanom. ${ }^{13}$ Najraniji pak trogirski zapisi o Vratkovićima odraz su neizvjesnih i konfuznih prilika na rubnim dijelovima Mletačke Dalmacije u periodu 1525. - 1530. godine kada novo stanovništvo zauzima napuštena sela.

Potkraj srpnja 1531. godine Petar, Andrija i Jakov Vratković dolaze pred trogirskoga kneza žaleći se na vojnike koji su ih, tobože bez razloga, napali pred gradskim vratima. No, svjedoci koje je knez potom ispitao, ne prešućujući incident koji se doista dogodio, kazali su da se radilo o reakciji na verbalnu, a zamalo i fizičku provokaciju. Naime, kako je to opisao jedan Trogiranin, Vratkovići su se vidno pijani doteturali do gradskih vrata 'časteći' usput stražare i druge koje su ondje zatekli brojnim uvredama (per lo imbriagezo fazeano mille deshonesta de tochar il cullo alle done che passauano per la strada et altri inconuenienti li seguittaua). Kada se jedan od Morlaka drznuo baciti kamen na slugu mletačkoga plaćenika Renessija, stražari su najprije riječima pokušali primiriti situaciju, a onda je Marco Polini, sin zapovjednika straže, otjerao jednoga morlačkoga konja, na što je njemu najbliži Vratković posegao za sabljom. Međutim, prije nego što ju je uspio isukati iz korica, jedan ga je od vojnika udario

10 Luca, “The Vlachs/Morlaks”, passim; Juran, "Doseljavanje Morlaka”, passim; Caciur, "Considerations Regarding the Status of the Morlachs", passim.

11 Kužić, "Prilog biografiji”, 213.

12 Kornelija Jurin Starčević, “Osmanski krajiški prostor: rat i društvo u jadransko-dinarskom zaleđu u 16. i 17. stoljeću” (doktorska disertacija, Sveučilište u Zagrebu, 2012), 177-178. O Vratkovićima u trogirskom distriktu podatke donosi i Catherine Wendy Bracewell, Senjski uskoci. Piratstvo, razbojništvo i sveti rat na Jadranu u šesnaestom stoljeću (Zagreb: Barbat, 1997), 190-198.

13 Bogumil Hrabak, "Naseljavanje hercegovačkih i bosanskih Vlaha u Dalmatinsku zagoru u XIV, XV i XVI veku”, u: Migracije i Bosna i Hercegovina: materijali s naučnog skupa Migracioni procesi i Bosna i Hercegovina od ranog srednjeg vijeka do najnovijih dana - njihov uticaj i posljedice na demografska kretanja i promjene u našoj zemlji, održanog u Sarajevu 26. i 27. oktobra 1989. godine, uredio Nusret Šehić (Sarajevo: Institut za istoriju, 1990), 67-87. Pregledali smo, naime, arhivski svezak na koji se Hrabak poziva, ali nismo naišli na spomenuti podatak o Vratkovićima. 
raskrvarivši mu glavu. Na to je ozlijeđeni, vičući "Pomagaj! Pomagaj!" (comenzo a cridar pomaga pomaga), zajedno sa svojim suplemenicima požurio do kneževe kancelarije. Možda bi trogirska javnost taj incident bila brzo zaboravila da sutradan nisu stigle uznemirujuće vijesti o osvetničkome pohodu očito ozlojeđenih Vratkovića, koji su svoju srdžbu iskalili na trojici nevinih ljudi. Odlazeći, naime, incidentnoga dana iz Trogira, zaustavili su se najprije u jednome vinogradu u Malome polju gdje je kao pudar boravio Cvitan s otoka Čiova. Prišli su pudaru pitajući ga ima li kakav sić da zagrabe vode iz obližnjega zdenca, a onda su ga bez ikakva povoda stali tući sjekirama i toljagama ostavivši ga raskrvavljenog, s porukom da izvijesti trogirskoga kneza tko ga je prebio. Zatim su kod Mezline, pod brdom Vlaško, presreli pastira Jurja iz Poljica, slugu trogirskoga plemića Petra de Andreisa, pa su i njega napali toljagama ostavivši ga napola mrtvog da leži na zemlji. Uputili su se dalje prema stražarskoj postaji na lokalitetu Vraca. Petar Vratković pozvao je stražara tražeći malo vode, a onda mu je, zajedno s drugim Morlacima, priredio sudbinu sličnu onoj koja je zadesila pudara Cvitana i pastira Jurja. Završna poruka napadača ista je u svim trima slučajevima: "Pođi trogirskome knezu i kaži mu da su te Vratkovići pretukli." Stradali je stražar kasnije izjavio da ga je najsilovitije udarao upravo Petar Vratković, kojega se i u zapisniku istrage, pri identifikaciji inkriminiranih Morlaka, uvijek stavlja na prvo mjesto. ${ }^{14}$

Trogirski knez, naravno, nije mogao učiniti ništa manje od kazne izgona Petra, Andrije i Jakova Vratkovića iz trogirskoga distrikta znajući vjerojatno da će takvu presudu biti teško provesti. Već u studenome iste godine Vratkoviće nalazimo kao protagoniste novoga sukoba unutar trogirskoga teritorija. Bilo je to kada se plemić Cippico spremao obići svoj posjed u selu Radošiću, nastanjenome novodoseljenim Morlacima. Svjestan mogućih neugodnosti poveo je sobom kao pratnju naoružane seljake. Kada su došli do predjela Tepla draga, presreli su ih Morlaci na konjima, naoružani kopljima i drugim oružjem. Krenuli su prema Cippicu prijeteći mu kopljima i uzvikujući: "Bre čoma! Bre čoma!" (Bre choma bre choma che vol dire in taliano taglia taglia). ${ }^{15} \mathrm{U}$ nastalome komešanju neki je seljak hicem iz puške usmrtio jednoga morlačkog konja, na što su se Morlaci dali u bijeg. Seljaci su pošli za njima, ali ih je Cippico, nastojeći spriječiti daljnje sukobe, pozvao natrag. Kao predvodnici incidenta prokazani su Petar, Andrija i Jakov Vratković, za koje se veli da su pod kaznom izgona, ali stanuju u Bristivici (!), zatim Antul Vratković, Ivan Vratković, Ivan Ćaleta od Vratkovića (de Vratcouichi) i njegov otac Radovan te još Radoslav Bubetić, Matijaš Bubetić i Radoslav Čulinović, Morlaci nastanjeni u Radošiću. ${ }^{16}$

Iz godine 1532. datiraju spomeni katunara Petra Vratkovića, a taj je po svoj prilici istovjetan incidentnom Petru, kojega smo upoznali u prethodnim retcima, i Jadri-

\footnotetext{
14 HR-DAZD-18-OT, kut. 5, fasc. 37.

15 Lingvističku problematiku zapisanoga uzvika, kako u pogledu jezične pripadnosti i glasovnog ostvaraja, tako i u pogledu semantike koja se po talijanskome ekvivalentu (taglia) može naslutiti, ostavljamo, naravno, lingvistima.

16 HR-DAZD-18-OT, kut. 3, fasc. 38, fol. 131r-134r.
} 
ja Petrovića de familia Vratchouich.$^{17}$ Četrnaest godina kasnije Trogirani se tuže na Vratkoviće jer su prestali plaćati ugovorenu zemljarinu. ${ }^{18}$ Matej Milatović "od Vratkovića” (de Uratchouichi) nalazio se 1548. godine u senjskome zarobljeništvu, a sljedeće ga je godine (ne znamo s kojim uspjehom) pokušala otkupiti njegova supruga, identificirana kao "Cvita od katuna Vratković" (Cuita de catuno Vratchocuich) ${ }^{19}$ Od ostalih podataka kojima raspolažemo izdvojit ćemo tri koja govore o prostornoj razmještenosti Vratkovićeva katuna. Nakon Ciparskoga rata 1575. godine Vratkovići se obvezuju da će vlasnicima zemalja na kojima obitavaju davati uobičajenu zemljarinu onako kako je to bilo određeno još 1534 . godine. Zastupao ih je tada Nikola pokojnoga Petra de Vratcouich catonarius ville Glubitouize et Dasini Dolci, Prapratniza Vraza et Bristiuiza ac aliarum. Nikola je u ispravi dodatno identificiran kao Mussulin habitator Glubitouize ville illorum de Andreis. ${ }^{20}$ Bio je, dakle, poznat i po nadimku Musulin, kojim će se kasnije služiti njegovi potomci, poput Marka i Mihovila Musulinovića iz Ljubitovice 1621. godine. ${ }^{21} \mathrm{U}$ jednoj pak ispravi iz 1589. godine zabilježeno je ime Mihovila Katunarovića "od sela Vratkovića to jest Ljubitovice" (de villa Vratcouich siue Gliubitouiza), ${ }^{22}$ dok se 1596. godine spominju stanovnici sela Bristivice, Vraca, Prapatnice, Dašinih Doca, Ljubitovice i Blizne, poznati pod zajedničkim imenom Vratkovići (tutti li habitatori delle infrascripte uille cioe Bristiuizza, Uraza, Prapratniza, Daxine Doce, Gliubitouizza et Blisna, tutti compresi sotto un nome di Vratcouichi). ${ }^{23}$ Prethodni se podaci bez teškoća mogu dovesti u vezu s osmanskim defterom iz 1550. godine gdje stoji da su na zahtjev primićura Ljubitovice Petra pokojnoga Dragića mezre Dašin Dolac, Smokvica, Podborajna, Blizna i Vinovac raspodijeljene nekim nomadima, očito Morlacima njegova katuna. ${ }^{24}$ Tako je izvjesno da su Petar pokojnoga Dragića i katunar Petar Vratković, zabilježen u ispravi 1532. godine, jedna te ista osoba. Onaj Nikola pokojnoga Petra, katunar Vratkovića 1575., vjerojatno je njegov sin. Vratkovići su, dakle, naseljavali šest sela (Ljubitovica, Bristivica, Prapatnica, Dašini Doci, ${ }^{25}$ Vraca i Blizna), a središnje, po svoj prilici i izvorište njihove početne iridijacije, bilo je u Ljubitovici gdje je prebivao katunar. Postoji, doduše, i podatak iz 1591. godine o čak dvanaest trogirskih sela pod zajedničkim imenom Vratkovići, ${ }^{26}$ no pret-

17 HR-DAZD-18-OT, kut. 13, fasc. 1, fol. 11r; HR-DAZD - fond 17 - Općina Šibenik (dalje: OŠ), kut. 10, fasc. 20/f.

18 Maria Pia Pedani, ur., Inventory of the Lettere e Scritture Turchesche in the Venetian State Archives (Leiden; Boston: Brill, 2010), 89.

19 HR-DAZD - fond 30 - Bilježnici Šibenika (dalje: ŠB), kut. 29/V, fasc. b, fol. 42v-43r; Juran, "Doseljavanje Morlaka”, 154.

20 HR-DAZD-18-OT, kut. 9, fasc. X.22, fol. 1182v-1183v.

21 Kristijan Juran, “Morlaci u Šibeniku između Ciparskoga i Kandijskog rata (1570. - 1645.)”, Povijesni prilozi 34 (2015), br. 49: 188.

22 HR-DAZD-18-OT, kut. 70, fasc. IX.18.19., fol. 437r.

23 HR-DAZD-18-OT, kut. 71, fasc. 71/2, fol. 212v.

24 Buzov, "Petrova gora, vlaška nahija", 317.

25 Na to da toponim valja čitati Dašini Do(l)ci, a ne Dasini Do(l)ci, upućuje grafija Daxine doce iz 1596. godine (vidi prethodni pasus gore u tekstu).

26 Commissiones et relationes Venetae, sv. 6, u: Monumenta spectantia historiam Slavorum meridionalum, sv. 48, prir. Grga Novak (Zagreb: JAZU, 1966), 13 i 32. 
postavljamo da je u tome slučaju riječ o (ne)namjernom izjednačavanju cjelokupnoga morlačkog stanovništva trogirske Zagore s njegovim najdominantnijim katunom. Najpotpunije podatke o stanovništvu tih naselja u 16. stoljeću pružaju objavljeni osmanski defteri iz 1550. i 1585. godine te jedan habsburški popis glavara obitelji iz 1579. objavljen u Spomenicima hrvatske Krajine R. Lopašića. ${ }^{27}$ Iako se njihovom usporedbom s demografskim vrelima idućih stoljeća (popis stanovnika iz 1630. i 1711. godine $)^{28}$ može doći do vrijednih spoznaja o kontinuitetu pojedinih rodova, cjelovitije zaključke u tome smislu priječi činjenica da su prezimena, poglavito u 16. stoljeću, još uvijek neustaljena, da ih vrela ne bilježe redovito te da se često zamjenjuju patronimima. Budući da mletački izvori, za razliku od osmanskih, češće posežu za prezimenskom oznakom identiteta, sljedeće retke ovoga poglavlja posvetit ćemo dosad neobjavljenim arhivskim bilješkama o pripadnicima Vratkovićeva plemena i to kao svojevrsnu predpripremu budućih genealoških istraživanja. Jednako ćemo postupiti i u sljedećim poglavljima, u kojima razmatramo druge plemenske zajednice.

Tako se u Bristivici spominju: 1537. Ivan Milovčević, Šimun Utihović, Radovan Ćaleta, Grgur Miloradović, Jakov Radivoja Vučetića, Ivan Radeljković i Ivan Jurjević; ${ }^{29}$ 1544. Divnići (illorum de Diuinich); ${ }^{30}$ 1569. Andrijan Ćaletić; ${ }^{31} 1575$. Ivanko Biloslavić, Nikola Hrastovačić, Brate Radićević, Juraj Milošević i Mate Jakovčić; ${ }^{32} 1586$. Pavao Radeljković rečeni Ivanišević; ${ }^{33} 1597$. Bartul Marojević. ${ }^{34}$ Svi su oni identificirani kao žitelji Bristivice, a ne kao pripadnici Vratkovića. No, ima i drukčijih primjera pa u spomenima Mateja Milatovića i Ivana Divnića “od Vratkovića” (1548.), Pavla Radeljkovića “od Vratkovića” (1573.) te Vuice i Bartola Marojevića “od Vratkovića” (1586.) prepoznajemo upravo Morlake nastanjene u Bristivici. ${ }^{35}$ Među svim ostalim antroponimijskim formulama na koje smo naišli pregledavajući trogirske arhivske zapise izdvaja se ona Ivanka Biloslavića "od Divnića” (1598.), ${ }^{36}$ koji je identificiran po svojoj obitelji/rodu (Divnići), a ne po oznaci teritorijalne (Bristivica) ili plemenske (Vratkovići) pripadnosti. Očito je da su Divnići u novonastajućemu društvenom tkivu trogirskoga pograničja prepoznati kao snažna obiteljska zajednica, o čemu svjedoči

27 Opširni popis Kliškog sandžaka iz 1550. godine, obradili Fehim Dž. Spaho i Ahmed Aličić, prir. Behija Zlatar (Sarajevo: Orijentalni institut, 2007), passim; Buzov, "Petrova gora, vlaška nahija", passim; Spomenici hrvatske Krajine. Knj. 1: od 1479. do 1610., u: Monumenta spectantia historiam Slavorum meridionalum, sv. 15, ur. Radoslav Lopašić (Zagreb: JAZU, 1884), 82-84.

28 Vjeko Omašić, Mletačko-tursko razgraničenje na trogirskom području nakon Ciparskog i Kandijskog rata i njegove posljedice (Trogir: Izdanje Muzeja grada Trogira, 1971), 42-45; Vjeko Omašić, "Katastik trogirskog dijela 'Nove stečevine' iz 1711. godine", Prilozi i građa za povijest Dalmacije 8 (1974): 95-152.

29 HR-DAZD-18-OT, kut. 69, fasc. 11, fol. 666r, 667-669v, 672v-673r.

30 HR-DAZD-18-OT, kut. 7, fasc. VIII.2, fol. 176r.

31 HR-DAZD-18-OT, kut. 7, fasc. VIII.5, fol. 395v.

32 HR-DAZD-18-OT, kut. 9, fasc. X.22, fol. 1182v-1183v.

33 HR-DAZD-18-OT, kut. 70, fasc. 17, fol. 624v.

34 HR-DAZD-18-OT, kut. 71, fasc. 71/2, fol. 273r.

35 HR-DAZD-30-ŠB, kut. 29/V, fasc. b, fol. 42v-43r; HR-DAZD-18-OT, kut. 10, fasc. 5, fol. 1043v; HR-DAZD-18-OT, kut. 75, fasc. Extraordinariorum primus, fol. 141v.

36 HR-DAZD-18-OT, kut. 71, fasc. 71/4, fol. 1058v. 
i zapis iz 1544. godine o šteti koju su učinili konji illorum de Diuinichi na usjevima u Mezlini. ${ }^{37}$ Njihova pretpostavljenoga rodonačelnika otkriva popis glavara obitelji u Bristivici iz 1550. godine gdje su, među ostalima, navedeni Ivan, sin Divnića i Radica, sin Divnića. ${ }^{38}$

Neka su prezimena na dijakronijskoj razini zajednička Bristivici i Prapatnici. Tako Ćalete (Ćaletiće) u 16. stoljeću nalazimo u Bristivici, a 1630. godine samo u Prapatnici. ${ }^{39} \mathrm{~S}$ druge strane, Vuica i Bartol Jurjevići iz Prapatnice (1579.) mogli bi biti istovjetni Vuici i Bartulu Marojevićima “od Vratkovića” (1583.), od kojih je drugonavedeni zabilježen i kao stanovnik Bristivice (1597.). ${ }^{40}$ Iz Prapatnice su Andrija Milatović (1537.), Radivoj Jakelić (1586.) i Marko Mamić (1590.). ${ }^{41}$ U Ljubitovici pak stoluju katunari, poput Petra Vratkovića, Nikole pokojnoga Petra rečenoga Musulina, a možda i Mihovila Katunarovića, o kojima je već bilo riječi. Bilježimo još Ivaniša Vladislavića de villa Gliubitouice (1537.) i njegova suseljanina Božu Radonjića (1598.). ${ }^{42}$

Kao žitelje Dašinih Doca nalazimo Martina Vukasovića (1537.), Budana i Miletu Spahijića (1575.), Dujma Novakovića (1585.) i Ivana Sabljića (1598.), ${ }^{43}$ dok su u Blizni stanovali Luka Stanić, Ivanko Jukić, Grgur Jukić, Martin Galić, Lovre Kodak (1575.), Vukman Pletković, Paval Milovčević (1586.), Božićko Pletković te braća Petar i Mile Jukići (1597.). ${ }^{44}$ Potonje vijesti o stanovništvu Blizne u velikoj se mjeri podudaraju s antroponimijom Blizne i susjedne Boraje u popisima iz 1579. i 1630. godine. To vrijedi za prezimena Galić, Pletkov/ić, Milovčić/Milovčević, Stanić, dok za prezime Luchich iz 1579. godine pretpostavljamo da je pogrešno upisano ili pročitano umjesto Jukić. ${ }^{45}$

\section{Popovići}

Prema izvoru iz druge polovice 17. stoljeća Popovići su obitavali na prostoru od Labina do Radošića. Vodeći se povijesno-geografskim kontekstom, nekim antroponomastičkim naznakama i istraživačkim oprezom, K. Kužić prepoznaje ih i kao stanovnike Suhoga Dola, to jest današnjega Primorskoga Doca. ${ }^{46}$ Valja, međutim, krenuti od činjenice da se morlačka zajednica Popovića u trogirskome distriktu spominje već 1530. godine kada su je opljačkali ljudi kliškoga kneza Petra Kružića. Zbog toga su incidenta mletačke vlasti prosvjedovale kod habsburških navodeći da je njihovim

37 HR-DAZD-18-OT, kut. 7, fasc. VIII.2, fol. 176r.

38 Opširni popis Kliškog sandžaka, 79.

39 Omašić, Mletačko-tursko razgraničenje, 42-45.

40 Spomenici hrvatske Krajine, 84; HR-DAZD-18-OT, kut. 75, fasc. Extraordinariorum primus, fol. 141v; HR-DAZD-18-OT, kut. 71, fasc. 71/2, fol. 273r.

41 HR-DAZD-18-OT, kut. 69, fasc. 11, fol. 663v; kut. 70, fasc. 17, fol. 623r; kut. 11, fasc. 11/5, fol. 18v.

42 HR-DAZD-18-OT, kut. 69, fasc. 11, fol. 663r; kut. 71, fasc. 71/2, fol. 397r.

43 HR-DAZD-18-OT, kut. 69, fasc. 11, fol. 667r; kut. 9, fasc. X.22, fol. 1182v-1183v; kut. 10, fasc. 17, fol. 327r; kut. 71, fasc. 71/2, fol. 393v.

44 Izvori su redom: HR-DAZD-18-OT, kut. 9, fasc. X. 22, fol. 1182v-1183v; kut. 70, fasc. 17, fol. 622r; kut. 70, fasc. 17, fol. 631r; kut. 71, fasc. 71/2, fol. 254r, 277r i 280v.

45 Spomenici hrvatske Krajine, 83; Omašić, Mletačko-tursko razgraničenje, 42-45.

46 Kužić, "Prilog biografiji”, 213. 
podanicima Popovićima, smještenima u predjelu Spicho, ukradeno stotinu konja, tisuću grla krupne te pet tisuća grla sitne stoke. ${ }^{47} \mathrm{Iz}$ tih se podataka mogu izvući tri važna zaključka. Prvo, Popovići u trogirskome distriktu borave u svojstvu mletačkih štićenika, to jest uz znanje i u dogovoru, formalnom ili neformalnom, prethodnom ili naknadnom, s trogirskom upravom. Drugo, broj ukradene stoke, iako očito preuveličan, svjedoči o dominantnome stočarskom habitusu i znatnim gospodarskim potencijalima oštećene morlačke zajednice. I treće, Popovići su boravili u mjestu Spicho, koje se može, s dužnim oprezom, dovesti u vezu s nestalim srednjovjekovnim naseljem Zbičje (danas dio Prgometa). To je naselje (i) 1532. godine, kada ga isprave bilježe u obliku Sbichie, bilo na udaru razbojnika različitih provenijencija. Pljačkali su ga i osmanski Morlaci i mletački izgnanici. Kako je već u uvodu ovoga priloga navedeno, vlasnici Zbičja bili su trogirski Andreisi, koji su ga 1534. godine dali u zakup Morlacima starješine Jurja Šimunića. Preuzetno bi bilo na ovome mjestu zaključiti da je dotični Šimunić bio starješina katuna Popović, ali se takva mogućnost ne može odbaciti. Zabunu unosi (i) događaj koji se zbio tri godine ranije kada su Morlaka Petra Pavlovića, stanovnika Zbičja (habitator in presentiarum a Sbichie territorii Tragurii), napala dvojica Kaštelana. Napadači su mu prišli misleći da je pripadnik roda Dobročevićev (Tu sei de queli bechi fotui de i Dobrozeuich!), s kojima su očito imali nekih razmirica, međutim, on ih je uvjeravao da nije u rodu s Dobročevićima nego član Borovaca (E son de una casada de Borouaze, io stago suso la villa de quelli de Andreis).$^{48}$ Daljnji tijek zbivanja ostavljamo spisima na čuvanje, a za našu je temu bitno da se Pavlović nije identificirao kao član Popovića, nego Borovaca. Je li riječ o katunu Borovac odnosnu katunu Zborovac/Zborovci, koji se spominju u više isprava iz 15. stoljeća, pitanje je koje ostavljamo otvorenim..$^{49}$ Jednako je teško dati jednoznačan odgovor na pitanja je li Zbičje i kasnije bilo naseljeno Popovićima i gdje se uopće ta morlačka zajednica nalazila prije dolaska na područje trogirskoga distrikta. Zbičje nije zastupljeno u osmanskim defterima iz 1550. i 1585. godine pa je moguće da ga je u tim vrelima prekrio neki od susjednih toponima. S druge strane, trogirski spisi znaju za Mateja Tomaševića, Morlaka de villa Zbichi (1537.) te Pavka Jurjevića i Vukosava Matijevića rečenoga Kovača de villa Sbichi (1546.). ${ }^{50}$

47 Habsburški spomenici Kraljevine Hrvatske, Dalmacije i Slavonije. Knj. 1: od godine 1526. do godine 1530., u: Monumenta spectantia historiam Slavorum meridionalum, sv. 35, ur. Emilij Laszowski (Zagreb: JAZU, 1914), 456: in loco quodam Spicho nominato, qui subest iurisdictioni Tragurii, quibusdam Murlachis cognominatis Popouichiis, eius loci inhabitatoribus. U literaturi postoji mišljenje da je dokument pogrešno datiran u 1530. umjesto u 1535. godinu (Bracewell, Senjski uskoci, 50, bilj. 73).

48 HR-DAZD-18-OT, kut. 6, fasc. 35, fol. 1r-10r.

49 Godine 1430. Stanoj iz katuna Borovac bio je dužnik nekoga Šibenčanina (HR-DAZD-30-ŠB, kut. 3/I, fasc. k, fol. 15r), a 1434. Vukša Radojković iz katuna Borovac boravi na zadarskome području (HR-DAZD - fond 31 - Bilježnici Zadra (dalje: ZB), Nicolaus de Ho de Cremona (1433. - 1436.), fasc. I/3, fol. 86r). Milisava iz katuna Zborovac dogovorila je 1456. godine udaju za jednoga stanovnika Žitnića u šibenskome distriktu (HR-DAZD-30-ŠB, kut. 16/IV, fasc. c, fol. 68v). Početkom 16. stoljeća spominje se Jelina, kći Blaža de Sborofzi (HR-DAZD-30-ŠB, kut. 28/I, fasc. c, fol. 9r).

50 HR-DAZD-18-OT, kut. 69, fasc. 11, fol. 661r; kut. 69, fasc. 13, fol. 86v. 
Ono što pak zasigurno znamo o Popovićima jest to da su bili prisutni u naseljima Suhi Dol i Kosmači. Na to izravno ukazuju podaci o Morlaku Mihovilu Popoviću iz Suhoga Dola (1548. $)^{51}$ te prezimenu Cerc(h)ovich, koje se u 16. stoljeću javlja u Suhomu Dolu, Kosmačima i selu Popović. ${ }^{52}$ Potonji podatak o selu imena Popović ukazuje na to da se pod tim imenom krije Suhi Dol ili pak Suhi Dol i susjedni Kosmači zajedno. Na taj se način može iščitati, primjerice, provenijencija Bože Lalića i Petra Lalića de Popouichi (1597./1598.). ${ }^{53}$ Dodajmo tim podacima i spomen iz 1623. godine o Morlaku prezimena Cercouich alias Popouich iz Suhoga Dola. ${ }^{54}$ O stanovništvu Suhoga Dola raspolažemo još nizom podataka. U njemu su 1537. godine stanovali Nikola Radićević, Šimun Vukomilović i Grgur, sin Marka Jeličića, ${ }^{55}$ ali i Petar Čerković (Cerchouich), sin Marojev, te njegov bratić Radoje, sin Jurjev, kao i Radivoj Lakosalić, koji se sljedeće godine bilježe kao uskoci, to jest prebjezi nastanjeni u Trogiru. ${ }^{56}$ Iz 1574 . godine potječu zapisi o Tomi Bakoviću i njegovu pokojnom bratu Radonji Bakiću (!) te o Juri Radiću i Tomi Miokoviću reč. Prlja (Miochouich alias Pargla). ${ }^{57}$ Kasnije se u istome selu spominju još Jakov Milin (1584.) i Ivan Veseličić (1590.). ${ }^{58}$

\section{Vasarovići}

Među Morlacima koji su 1575. godine, nakon završetka Ciparskoga rata, obnovili četrdeset godina stare zemljišne ugovore s trogirskim zemljoposjednicima bio je i Jakov Vasarović, katunar i starješina sela Trolokve te starješina svih drugih od plemena Vasarovića (Iacobus Vassarouich catonarius et caput ville Triloque illorum de Claudiis (...) ac aliorum de dicta familia de Vassarouich). ${ }^{59}$ Dotični je katunar po svoj prilici istovjetan Jakovu, sinu Vasava, koji je naveden na prvome mjestu u popisu osmanskih poreznih obveznika u Trolokvama 1550. godine ${ }^{60}$ kao i Jakovu Vasaroviću rečenome Bašiću, spomenutome u istome selu 1574. godine. ${ }^{61}$ Očito je da Vasarovićev katun svoje ime duguje ili Jakovljevu ocu Vasavu ili nekome njihovom zajedničkom pretku istoga imena. Kao u slučaju Vratkovića i Popovića, i kod identifikacije pripadnika katuna Vasarovića plemensko ime ponekad zamjenjuje toponimsku odrednicu. Tako se za braću Iliju i Mateja Prnjakovića (Pargnacouih) 1597. veli da su "od Vasarovića"

Prezime je vjerojatno glasilo Čerković, na što upućuje dvojna grafija Cerchouich/Zerchouich iz 1538. godine za prezime Morlaka iz Suhoga Dola (HR-DAZD-18-OT, kut. 4, fol. 146v i dalje). Godine 1590. spominju se Marko i Radič Cercouich, Morlaci de villa Cosmaz (HR-DAZD-18-OT, kut. 11, fasc. 11/5, fol. 17v). Usp. i Kužić, "Prilog biografiji", 212.

53 HR-DAZD-18-OT, kut. 71, fasc. 71/2, fol. 272v, 395v.

54 HR-DAZD-18-OT, kut. 91, fasc. Instrumentorum quintum, fol. 11v.

55 HR-DAZD-18-OT, kut. 69, fasc. 11, fol. 669r, 673r, 674r.

56 HR-DAZD-18-OT, kut. 4, fol. 146v i dalje.

57 HR-DAZD-18-OT, kut. 13, fasc. XVI.11, fol. 6v i 23v.

${ }_{58}$ HR-DAZD-18-OT, kut. 75, fasc. Extraordinariorum tertius, fol. 234r; kut. 11, fasc. 11/5, fol. 19v.

59 HR-DAZD-18-OT, kut. 9, fasc. X.22, fol. 1182v-1183v.

60 Opširni popis Kliškog sandžaka, 74.

${ }^{61}$ HR-DAZD-18-OT, kut. 13, fasc. 11, fol. 5r. 
(de Vassarouichi), a za Marka Prnjakovića 1598. da je iz Trolokava. ${ }^{62}$ Kao pripadnici Vasarovića spominju se 1585. godine Juraj Marković i 1598. Mirčeta [Suscouich], ${ }^{63}$ a kao stanovnike Trolokava nalazimo još Bartola Bakića (1569.), Pavla Bakića rečenoga Bašića i Mihovila Zloću (1574.) te Miloša Bakića (1598.). ${ }^{64}$

Zasad ne raspolažemo saznanjima jesu li Vasarovići u 16. stoljeću bili prisutni u još kojemu selu trogirske Zagore. Ukazujemo, međutim, na svjedočanstva nešto šire prostorne disperzije plemenskoga imena (ako je u tim slučajevima uopće riječ o istome plemenu): 1540. Morlak Juraj Vasarović iz Dugopolja u Splitu prodaje kobilu; ${ }^{65} 1591$. spomenut je Vuica Radmilović “od Radmilovića iliti Va[sa]rovića”; ${ }^{66}$ 1596. prezime Vasarović potvrđeno je u Sukošanu, a kasnije (od 1626.) u Bibinjama. ${ }^{67}$ Ukazujemo također na moguće povijesnodemografske relacije između trogirskih Vasarovića i zapadnohercegovačkoga sela Vašarovići u blizini Ljubuškoga.

\section{Morlaci u drugim trogirskim selima}

Osim Vratkovića, Popovića i Vasarovića, drugih morlačkih zajednica s prepoznatljivim rodovskim odnosno teritorijalnim imenom u trogirskome distriktu ili nije bilo ili ih u izvorima nismo prepoznali. Jedina trogirska naselja "preko brda" (oltra il monti), koja su prema dosad proučenim izvorima ostala izvan demografskih dosega navedenih triju plemena, jesu Labin, Radošić, Prgomet i Opor. Najranije vijesti o novim doseljenicima u Labinu pripadaju 1531. godini kada je Mihovil Berčić s otoka Čiova Morlacima Petru Biloslaviću i Nikoli Ivkoviću appresso Labin ukrao dva konja. ${ }^{68} \mathrm{Iv}$ kovići se u Labinu spominju i 1546. i 1596. godine. ${ }^{69} \mathrm{U}$ tome su naselju zabilježeni još Vukas Bubić, Andrija Lasinović i Jure Martinović 1537., Paval Mr(k)šić 1547., Ivko Giljanović 1548., Vukman Papić 1597. i Raosav Vlaičić 1599. godine. ${ }^{70}$ Prezime Vlaičić prisutno je u 16. stoljeću i u susjednome Oporu pa je moguće da su u Labinu i Oporu živjeli pripadnici iste morlačke zajednice. ${ }^{71}$

Starješina novih doseljenika u Radošiću 30-ih godina 16. stoljeća bio je Radoslav Bubetić. Uz njega se 1531. godine spominju Matijaš Bubetić i Radoslav Čulinović, ${ }^{72}$ a 1534. godine, kada je zastupao svoju zajednicu pri sklapanju zemljišnoga ugovora s

\footnotetext{
62 HR-DAZD-18-OT, kut. 71, fasc. 71/2, fol. 238r; kut. 71, fasc. 71/2, fol. 380v.

63 HR-DAZD-18-OT, kut. 75, fasc. Bulletarum mercium, fol. 1062r; kut. 71, fasc. 71/4, fol. 1058v.

64 HR-DAZD-18-OT, kut. 7, fasc. VIII.5, fol. 395r; kut. 13, fasc. XVI.11, fol. 18v; kut. 71, fasc. 71/2, fol. 267.

65 HR-DAZD - fond 16 - Općina Split, kut. 84, fasc. 5, fol. 399v.

66 Slova koja u izvornome zapisu nismo sa sigurnošću identificirali označili smo uglatim zagradama.

67 HR-DAZD-31-ZB, Francesco Primizio (1590. - 1606.), busta I, fasc. I/6, 18. siječnja i 28. siječnja 1596.; Zuanne Braicich (1621. - 1645.), busta II, fasc.. II/22, fol. 36r-37r.

68 HR-DAZD-18-OT, kut. 6, fasc. 35, fol. 11r i dalje.

69 HR-DAZD-18-OT, kut. 69, fasc. 13, fol. 19v; kut. 71, fasc. 71/2, fol. 396r.

70 HR-DAZD-18-OT, kut. 69, fasc. 11, fol. 670v i 673v; kut. 69, fasc. 13, fol. 140v i 196v; kut. 71, fasc. 71/2, fol. 254v; Juran, "Morlaci u Šibeniku”, 187.

71 HR-DAZD-18-OT, kut. 75, fasc. Damnorum dationum primus, fol. 918r.

72 HR-DAZD-18-OT, kut. 3, sign. 37, fol. 87r-90v.
} 
vlasnicima Radošića Cippicima, u njegovoj su pratnji bili Ivan Vukašin, Petar Ivanović, Juraj Radovanović, Ivan Petrović i Maroj Ljubišić. ${ }^{73}$ Tijekom rata 1537. - 1540. Radošić je bio napušten. ${ }^{74}$ Nije nam poznato jesu li se u njega kasnije vratili predratni Morlaci ili ga je možda naselila neka druga morlačka skupina.

O drugim je naseljima malo podataka, što ne znači da će se to isto moći ustvrditi kada se vrela trogirske ali i drugih provenijencija obrade detaljnije i cjelovitije. Otegotna je okolnost i to što imena nekih sela i mezri iz osmanskih deftera nismo uspjeli prepoznati u trogirskim spisima. ${ }^{75}$ Ojkonimijske nepodudarnosti toga tipa, pa tako i posljedične neusklađenosti morlačkih plemenskih topografija, i dalje ostaju otvorenim pitanjima. Nadamo se da je ovaj prilog ipak upotpunio neke praznine i otvorio prostor budućim istraživanjima.

\section{Zaključak}

Osmanska pustošenja u drugoj polovici 15. stoljeća znatno su razrijedila demografski korpus rubnih dijelova Mletačke Dalmacije. To se osobito pokazalo u slučaju trogirskih i šibenskih sela (Zagora), koja su konačno napuštena tijekom Mletačko-osmanskoga rata od 1499. do 1502. godine. Na taj se prostor u trećemu desetljeću 16. stoljeća naseljavaju osmanski Morlaci, podrijetlom (uglavnom) iz Hercegovine. Balansirajući na osjetljivu pograničnome prostoru, stiješnjeni okvirima mletačko-osmanskih diplomatskih razmirica, Morlaci su uspjeli legalizirali svoj naseljenički status i to sklapanjem zemljišnih ugovora s vlasnicima sela koja su zaposjeli. Ipak, neriješena jurisdikcijska pitanja u kontekstu mletačko-osmanskih odnosa ostat će trajnim obilježjem kako općenito dalmatinske, tako posebno šibenske i trogirske povijesti 16. stoljeća.

U ovome smo istraživanju, koristeći uglavnom arhivske spise trogirske provenijencije, nastojali prepoznati imena morlačkih katuna koji se u opisanim povijesnim okolnostima pojavljuju na trogirskome području te uočiti njihovu prostornu distribuciju unutar trogirskoga distrikta. Opisali smo također nekolicinu događaja koji svjedoče o sukobima između Morlaka i mletačkih podanika u početnome razdoblju njihove socijalne interakcije. Primijetili smo da je najveći dio doseljenih Morlaka pripadao plemenskim skupinama Vratkovića, Popovića i Vasarovića. Vratkovići, pristigli iz Hercegovine, bili su najbrojniji. Naseljavali su šest sela: Ljubitovicu, Bristivicu, Prapatnicu, Dašine Doce, Vraca i Bliznu. Sijelo njihova starješine (katunara) bilo je u Ljubitovici. Popovići se 1530. godine spominju u Zbičju (sjeveroistočni dio današnjega Prgometa), a kasnije su potvrđeni u Suhome Dolu i Kosmačima (današnji Primorski Dolac). Vasarovići su bili smješteni u Trolokvama, a svoje plemensko ime po svoj

73 Caciur, "Considerations Regarding the Status of the Morlachs", 100.

74 HR-DAZD-18-OT, kut. 80, fasc. 85/1, fol. 453v-454r.

75 U defteru iz 1585. godine, primjerice, nakon Labina i Opora upisano je selo Sinokoš gdje stanuju Mile, sin Jurkov i Budiša, sin Jurjev (Buzov, "Petrova gora, vlaška nahija”, 335). Tome toponimu zasad nismo ušli u trag u trogirskim spisima, ali moguću poveznicu nalazimo na polju antroponimije u spomenu Budana i Mile Spahijića iz Dašinih Doca 1575. godine (HR-DAZD-18-OT, kut. 9, fasc. X.22, fol. $1182 \mathrm{v}-1183 \mathrm{v}$ ). 
prilici duguju Vasavu, ocu Jakovljevu, koji je 1550. godine bio seoski starješina. Zasad nismo uočili neposredne veze (osim u imenu) između trogirskih Vasarovića i stanovnika zapadnohercegovačkoga naselja Vašarovići iako se one mogu pretpostaviti. Iznosimo, na koncu, opći zaključak da su morlačke zajednice Vratkovića, Popovića i Vasarovića u 16. stoljeću demografski prekrile dvije trećine naselja u zaleđu Trogira, “iza brdâ”, unutar trogirskoga distrikta, uz mogućnost da će ih buduća istraživanja prepoznati i u kojemu naselju preostale trećine, primjerice u Labinu, Oporu, Prgometu ili Radošiću. O pretpostavljenim, pak, i nazirućim kontinuitetima pojedinih morlačkih rodova trogirske Zagore od 16. stoljeća do recentnoga doba, o čemu sada imamo novih spoznaja, valjat će također utemeljiti zasebna istraživanja. 


\section{Neobjavljeni izvori}

Hrvatska - Državni arhiv u Zadru, Zadar - fond 17 - Općina Šibenik (HR-DAZD-17-OŠ) Hrvatska - Državni arhiv u Zadru, Zadar - fond 18 - Općina Trogir (HR-DAZD-18-OT) Hrvatska - Državni arhiv u Zadru, Zadar - fond 30 - Bilježnici Šibenika (HR-DAZD30- ̌̌B)

Hrvatska - Državni arhiv u Zadru, Zadar - fond 31 - Bilježnici Zadra (HR-DAZD-31-ZB)

\section{Objavljeni izvori i literatura}

Bracewell, Catherine Wendy. Senjski uskoci. Piratstvo, razbojništvo i sveti rat na Jadranu u šesnaestom stoljeću. Zagreb: Barbat, 1997.

Buzov, Snježana. "Petrova gora, vlaška nahija”. Godišnjak Titius: godišnjak za interdisciplinarna istraživanja porječja Krke 4 (2011), br. 4: 313-361.

Caciur, Dana. "Considerations Regarding the Status of the Morlachs from the Trogir's Hinterland at the Middle of the 16th Century: Being Subjects of the Ottoman Empire and Land Tenants of the Venetian Republic". Res Historica: czasopismo Instytutu Historii UMCS 41 (2016): 95-110.

Commissiones et relationes Venetae, sv. 6. U: Monumenta spectantia historiam Slavorum meridionalum, sv. 48, priredio Grga Novak. Zagreb: JAZU, 1966.

Habsburški spomenici Kraljevine Hrvatske, Dalmacije i Slavonije. Knj. 1: od godine 1526. do godine 1530. U: Monumenta spectantia historiam Slavorum meridionalum, sv. 35, uredio Emilij Laszowski. Zagreb: JAZU, 1914.

Hrabak, Bogumil. "Naseljavanje hercegovačkih i bosanskih Vlaha u Dalmatinsku zagoru u XIV, XV i XVI veku”. U: Migracije i Bosna i Hercegovina: materijali s naučnog skupa Migracioni procesi i Bosna i Hercegovina od ranog srednjeg vijeka do najnovijih dananjihov uticaj i posljedice na demografska kretanja i promjene u našoj zemlji, održanog u Sarajevu 26. i 27. oktobra 1989. godine, uredio Nusret Šehić, 67-87. Sarajevo: Institut za istoriju, 1990.

Jakovljević, Aleksandar, Isailović, Neven. Petrovo polje u vrelima osmanskog razdoblja (1528. - 1604.). Šibenik: Državni arhiv u Šibeniku; Javna ustanova Nacionalni park Krka, 2019.

Juran, Kristijan. “Doseljavanje Morlaka u opustjela sela šibenske Zagore u 16. stoljeću”. Povijesni prilozi 33 (2014), br. 46: 129-160.

Juran, Kristijan. "Morlaci u Šibeniku između Ciparskoga i Kandijskog rata (1570. 1645.)". Povijesni prilozi 34 (2015), br. 49: 163-210.

Jurin Starčević, Kornelija. "Osmanski krajiški prostor: rat i društvo u jadransko-dinarskom zaleđu u 16. i 17. stoljeću”. Doktorska disertacija, Sveučilište u Zagrebu, 2012.

Kužić, Krešimir. "Prilog biografiji nekih Kačićevih vitezova te podrijetlu stanovništva njihova kraja”. Radovi Zavoda za povijesne znanosti HAZU u Zadru 47 (2005): 191-224. 
Luca, Cristian. "The Vlachs/Morlaks in the Hinterlands of Traù (Trogir) and Sebenico (Šibenik), Towns of the Venetian Dalmatia, during the 16th century". U: Miscellanea Historica et Archaeologica in Honorem Professoris Ionel Cândea, ur. Valeriu Sîrbu, Cristian Luca, 313-361. Braila: Editura Istros a Muzeului Brailei, 2009.

Omašić, Vjeko. Mletačko-tursko razgraničenje na trogirskom području nakon Ciparskog i Kandijskog rata i njegove posljedice. Trogir: Izdanje Muzeja grada Trogira, 1971.

Omašić, Vjeko. “Katastik trogirskog dijela 'Nove stečevine' iz 1711. godine”. Prilozi i građa za povijest Dalmacije 8 (1974): 95-152.

Opširni popis Kliškog sandžaka iz 1550. godine, obradili Fehim Dž. Spaho i Ahmed Aličić, priredila Behija Zlatar. Sarajevo: Orijentalni institut, 2007.

Pedani, Maria Pia, ur. Inventory of the Lettere e Scritture Turchesche in the Venetian State Archives. Leiden; Boston: Brill, 2010.

Spomenici hrvatske Krajine. Knj. 1: od 1479. do 1610. U: Monumenta spectantia historiam Slavorum meridionalum, sv. 15, uredio Radoslav Lopašić. Zagreb: JAZU, 1884. 
Kristijan Juran

\section{Tribe Vratković and other Morlachs in the 16th Century Trogir District}

\section{Summary}

Recent historiography has produced a number of notable works on the Venetian-Ottoman relations at the border of Trogir in the $16^{\text {th }}$ century and the role of the newly settled Ottoman Morlachs therein. This paper is a contribution to the understanding of these relations, its research sensors focusing primarily on the previously unpublished archival data about the presence of the Morlach tribes (Katuns) in individual villages of the Trogir district in the period from 1530 to 1600 . It has been noted that the majority of the newly arrived Morlachs belonged to the tribal groups of Vratković, Popović, and Vasarović. The Vratković tribe, which came from Herzegovina, was the most numerous. They inhabited six villages - Ljubitovica, Bristivica, Prapatnica, Dašini Doci, Vraca, and Blizna. The village of their elder (Katunar) was in Ljubitovica. The Popović tribe is mentioned in 1530 in Zbičje (the north-eastern part of present-day Prgomet) and later recorded in Suhi Dol and Kosmači (present-day Primorski Dolac). The Vasarović tribe was located in Trolokve and most probably owes its tribal name to Vasav, the father of Jacob, who in 1550 was the village's elder. Thus, the three Morlach communities demographically covered two-thirds of the settlements in the hinterland of Trogir, the area "behind the hills," and the Trogir district. Perhaps future research will identify them also in the remaining third, for instance in Labin, Opor, Prgomet, and Radošić.

Keywords: Morlachs, Vratković tribe, Popović tribe, Vasarović tribe, Trogir, Zagora, $16^{\text {th }}$ century

Kristijan Juran, Department of History, University of Zadar, Ruđera Boškovića 5, 23000 Zadar, Croatia,E-mail: kjuran@unizd.hr 